УДК 677.017.4:677.075

https://doi.org/10.35546/kntu2078-4481.2020.4.12

С.Ю. БОБРОВА

Київський національний університет технологій та дизайну, Україна

ORCID: 0000-0002-3381-9915

О.М. ДМИТРИК

Київський національний університет технологій та дизайну, Україна

Л.Є. ГАЛАВСЬКА

Київський національний університет технологій та дизайну, Україна ORCID: 0000-0002-6994-6641

\title{
СТІЙКІСТЬ ТРИКОТАЖУ 3 ВИСОКОМЦЦИХ ПОЛІЕТИЛЕНОВИХ НИТОК ДО ДІї РОЗДИРАЮЧОГО ЗУСИЛЛЯ ТА ПРОКОЛУ
}

\begin{abstract}
Одним з актуальних напрямів розвитку на сьогоднішній день $є$ виробництво засобів індивідуального захисту від небезпечних механічних впливів, щзо використовуються в умовах різних промислових виробнищтв. До цієё групи виробів відносять рукавички і рукавні вироби, щзо захищають різні ділянки рук - долоні, зап'ястя, передпліччя від порізів, проколів, вібрацій або тертя при роботі з гострими ріжучо-колючими предметами, виготовлених $з$ різних видів матеріалів. $У$ роботі запропоновано даний асортимент виготовляти на двофонтурному плосков'язальному обладнанні 3 наявністю платин за безшовною технологією. Перевагою суцільнов'язаних виробів є зручність в одяганні і високий комфорт при виконанні професійних завдань. Для надання необхідних характеристик міцності i стійкості до дії різних механічних впливів рекомендовано використання в структурі трикотажу ниток з надміцного високомолекулярного поліетилену.

Для захисних рукавичок і рукавних виробів обрано кулірний трикотаж переплетення гладь $i$ футероване на базі гладі. Для надання виробам достатньої пружності та еластичності в структуру введена еластомерна нитка у вигляді футерних накидів та протяжск з рапортом прокладання по ширині $1+3$ в кожному четвертому петельному ряді. Визначено параметри структури та механічні властивості трикотажу: стійкість матеріалу до роздирання і проколу.

Дослідження з визначення величини опору проколу розроблених зразків трикотажу проведені на розривній машині Као Tieh моделі KT-7010AZ відповідно до національного стандарту, гармонізованого $з$ європейським. Встановлено стійкість трикотажу до проколу в залежності від довжини нитки в петлі. У ході досліджень вивчено характер проколу, а саме деформачію зразка та характер руйнування структури під дією перфоруючого зусилля. Встановлено ступінь впливу шільності в'язання на механізм деформачії і характер проколу структури трикотажу.

Дослідження стійкості трикотажу до роздираючого зусилля проведено у відповідності до ДСТУ ЕN 388:2005. Прочес роздирання здійснювався як уздовж лінії петельного стовпчика, так $i$ вздовж лінії петельного ряду. У результаті проведених досліджень встановлено рівень роздираючого зусилля та характер руйнування дослідних зразків трикотажу переплетень гладь та футероване.

Ключові слова: захисні рукавички та рукави, високоміцній трикотаж, роздирання, прокол, високомолекулярна поліетиленова нитка.
\end{abstract}

С.Ю. БОБРОВА

Киевский национальный университет технологий и дизайна, Україна

ORCID: 0000-0002-3381-9915

О.М. ДМИТРИК

Киевский национальный университет технологий и дизайна, Україна

Л.С. ГАЛАВСЬКА

Киевский национальный университет технологий и дизайна, Україна

ORCID: 0000-0002-6994-6641

\section{УСТОЙЧИВОСТЬ ТРИКОТАЖА ИЗ ВЫСОКОПРОЧНЫХ ПОЛИЭТИЛЕНОВЫХ НИТЕЙ К ДЕЙСТВИЮ РАЗДИРАЮЩЕГО УСИЛИЯ И ПРОКОЛА}

Одним из актуальных направлений развития на сегоднямний день является производство средств индивидуальной защить от опасных механических воздействий, используемых в условиях различных промышленных производств. К этой группе изделий относят перчатки и рукавные изделия, защчищающие различные участки рук - ладони, запястья, предплечья от порезов, проколов, вибраций или 
трения при работе с острыми режуще-колющиими предметами, изготовленных из различных видов материалов. В работе предложено данный ассортимент изготавливать на двухфонтурном плосковязальном оборудовании с наличием платин по бесшовной технологии. Преимуществом иельновязанных изделий является удобство в одевании и высокий комфорт при выполнении профессиональных задач. Для придания необходимых характеристик прочности и устойчивости к воздействию различных механических воздействий рекомендуется использование в структуре трикотажа нитей из сверхпрочного высокомолекулярного полиэтилена.

Для защитных перчаток и рукавных изделий выбран кулирный трикотаж переплетения гладь $и$ футерованное на базе глади. Для придания изделиям достаточной упругости и эластичности в структуру введена эластомерная нить в виде футерных набросков и протяжек с раппортом прокладывания по ширине $1+3$ в каждом четвертом петельном ряду. Определень параметры структуры и механические свойства трикотажа: устойчивость материала к раздиранию и проколу.

Исследования по определению величинь сопротивления проколу разработанных образиов трикотажа проведены на разрывной машине Као Тіеһ модели КT-7010AZ в соответствии с национальным стандартом, гармонизированным с европейским. Установлена устойчивость трикотажа к проколу в зависимости от длинь нити в петле. В ходе исследований устойчивости трикотажа к проколу изучен характер прокола, а именно деформация образца и характер разрушения структуры под действием перфорирующего усилия. Установлена степень влияния плотности вязания на механизм деформации и характер прокола структуры трикотажа.

Исследование устойчивости трикотажа к раздирающему усилию проведено в соответствии с ДСТУ ЕN 388:2005. Процесс раздирания осуществлялся как вдоль линии петельного столбика, так и вдоль линии петельного ряда. В результате проведенных исследований установлено уровень раздирающего усилия и характер разрушения опытных образиов трикотажа переплетений гладь и футерованное.

Ключевые слова: защитные перчатки и рукава, высокопрочный трикотаж, раздирание, прокол, высокомолекулярная полиэтиленовая нить.

S.Yu. BOBROVA

Kyiv National University of Technologies and Design

ORCID: 0000-0002-3381-9915

O.M. DMYTRYK

Kyiv National University of Technologies and Design

L.Ye. HALAVSKA

Kyiv National University of Technologies and Design ORCID: 0000-0002-6994-6641

\section{RESISTANCE OF ULTRA-STRONG POLYETHYLENE YARN KNITWEAR TO TEARING AND PUNCTURE}

One of the priorities of today development is the production of personal protective equipment against dangerous mechanical influences used in various industrial productions. This group of products includes gloves and sleeves protecting various parts of the hands - palms, wrists, forearms from cuts, punctures, vibrations or friction when working with sharp cutting and piercing objects made of various materials. The paper proposes to produce this assortment on double-flat-knitting equipment with sinkers using seamless technology. The advantage of knitted seamless goods is ease of dressing and high comfort when performing professional tasks. To impart the necessary characteristics of strength and resistance to the effects of various mechanical influences, it is recommended to use yarn made of ultra-strong high molecular weight polyethylene in the knitted fabric structure.

To make a knitted gloves and sleeves, we chose a weft knit plain structure and a fleecy on the basis of a plain structure. To give the products sufficient stretch and elasticity, an elastomeric thread is introduced into the structure under the form of a fleecy tuck with a coursewise laying pattern of 1+3 in every fourth course. The structure parameters and mechanical properties of knits are determined: resistance of the material to tearing and puncture.

Studies of the puncture resistance value of the developed knitted structure samples are determined on tensile-testing machine Kao Tieh KT-7010AZ in accordance with national standart, harmonized with the European one. The resistance of knitwear to puncture has been determined depending on the loop length. In the course of the research of knitwear puncture resistance, the puncture nature was studied, namely the deformation of the sample and the failure behavior of the knitting structure under the action of the perforating force. The 
degree of influence of the knitting density on the deformation mechanism and the puncture nature of the knitted fabric structure has been established.

Studies of the tearing resistance of knitwear are determined in accordance with DSTU EN 388:2005. The tearing process was carried out both along the wale and along the course of knitted fabrics. As a result of the research, the level of tearing force and the failure behavior of knitted samples of plain and a fleecy structure.

Keywords: protection gloves and sleeves, ultra strong knitwear, tearing, puncture, ultra-high molecular weight polyethylene yarn.

\section{Постановка проблеми}

Виробництво надміцного трикотажу технічного призначення $\epsilon$ перспективним напрямком $\mathrm{i}$ охоплює широкий спектр матеріалів та виробів для побутової, промислової, військової сфери та спорту. Особливо затребуваним напрямом розвитку на сьогоднішній день $\epsilon$ виробництво засобів індивідуального захисту від небезпечних механічних впливів, що використовуються в умовах різних промислових виробництв. Передусім, до такої групи виробів відносять рукавички і рукавні вироби, що захищають різні ділянки рук - долоні, зап'ястя, передпліччя від порізів, проколів, вібрацій або тертя при роботі $з$ гострими ріжучо-колючими предметами, виготовлених з різних видів матеріалів (скло, метал, кераміка та ін.) [1]. Сучасні засоби захисту рук виготовляються за двома технологіями - пошиття і в'язання, а в їх структуру вводиться нитки підвищеної міцності, серед яких особливим попитом користуються нитки 3 надвисокомолекулярного поліетилену з їх унікальними фізико-механічними властивостями, що надають виробам високі показники міцності і стійкості до дії різних механічних впливів. Відсутність досвіду переробки нової сировини на вітчизняних трикотажних підприємствах призводить до виникнення певних труднощів і потребує вдосконалення технології їх переробки, налагодження роботи механізмів під нові вимоги, а вибір виду переплетення та параметрів іх структури стає дуже впливовим фактором на властивості готових полотен та виробів.

\section{Аналіз останніх досліджень і публікацій}

Виготовлення спеціальних захисних рукавичних виробів на в'язальних автоматах за безвідходною технологією має значні переваги перед розкрійним способом. Для суцільнов'язаних виробів характерні зручність в одяганні і високий комфорт при виконанні професійних завдань. Основні показники якості засобів індивідуального захисту рук $є$ безпека, міцність і зносостійкість. Відповідно до [2] захисні рукавички повинні проходити випробування на стирання, поріз, роздирання і прокол. Крім того, суцільнов'язані рукавні вироби повинні відповідати вимогам за ергономічними властивостями мати достатню розтяжність, еластичність і пружність для забезпечення легкості одягання й зручності виконання роботи в умовах виробництва [3].

Науковцями ведеться постійна робота у напряму створення нових матеріалів для засобів індивідуального захисту від механічних небезпек на виробництві; використання різних структур 3 вмістом високоміцних ниток, таких як параарамідні, метаарамідні, скляні, карбонові, металеві та високомолекулярні поліетиленові задля підвищення рівня захисту співробітників у цехах, де існує небезпека професійних травмувань гострими предметами [4]. Залежно від виду сировини та структури трикотажного переплетення, що використані при виготовленні засобів захисту рук, вироби будуть відрізняються за своїми захисними характеристиками і відповідно сферою застосування [5]. Тому для переробки у трикотажні вироби, що використовуються при прямому контакті з гострими або колючими предметами, обрано нитку з надміцного поліетилену UHMW PE (ultra-high molecular weight polyethylene). Комплекс іiї позитивних характеристик забезпечує необхідні показники якості готовим виробам - високу міцність і стійкість до дії механічних навантажень.

У роботах $[6,7]$ розглянуто питання розробки виду переплетення трикотажу для засобів захисту рук від механічних ушкоджень, його деформаційні властивості, а також стійкість до дії порізу. В роботі [8] проведено глибокий аналіз властивостей надміцного трикотажу технічного призначення, запропонована технологія в'язання трикотажного рукава на двофонтурній плосков'язальній машині, визначено розривальні характеристики трикотажу та досліджено його стійкість до стирання. В рамках даної роботи розглянуто стійкість трикотажу з високоміцних поліетиленових ниток до дії роздираючого зусилля і проколу.

Для реалізації поставленої у роботі задачі використано високомолекулярну поліетиленову нитку торгової марки Doyentrontex компанії «Beijing Tong yi zhong» (Китай), що перероблюється у трикотажні нарукавники (трубчастий виріб без пальців) і рукавички [9]. Трикотаж вироблено на двофонтурному обладнанні з язичковими голками з наявністю платин, які забезпечують зосереджене виконання окремих операцій петлетворення, - надійно фіксують нитку під час ії входження під крючок голки і формування петель, створюють іiї постійний натяг, що сприяє безперешкодному формуванню петель мінімальної довжини. Для перевірки відповідності вимогам по показникам стійкості розроблених зразків трикотажу захисних рукавних виробів до механічних навантажень, здійснено дослідження їх опору дії роздираючого зусилля та проколу. 


\section{Формулювання мети дослідження}

Метою даної роботи є дослідження впливу щільності в'язання кулірного трикотажу та структури переплетення на стійкість трикотажу з високоміцних поліетиленових ниток до дії роздираючого зусилля та проколу.

\section{Викладення основного матеріалу дослідження}

Для трикотажного рукава і рукавичок обрано кулірний трикотаж переплетень гладь і футероване на базі гладі 3 використанням поліетиленової нитки лінійної густини 132 текс у поєднанні 3 еластомерною ниткою типу спандекс 100 текс у якості футерної (рис.1). Еластомерна нитка введена в структуру у вигляді футерного накиду з рапортом прокладання по ширині 1+3 в кожному четвертому петельному ряді.

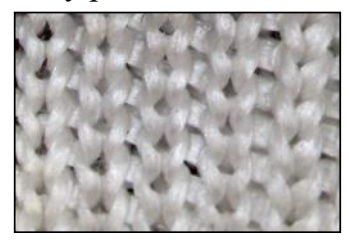

a -переплетення гладь

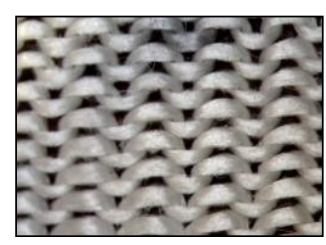

Рис.1. Зображення трикотажу для суцільнов'язаних захисних виробів (лицьова та виворітна сторони відповідно без і 3 еластомерною ниткою)

Трикотажні вироби вироблені за безшовною технологією, яка забезпечує готовому виробу високі ергономічні характеристики. Запропоновані структури забезпечують достатню щільність, пружність і надійне облягання виробом кінцівки при високих показниках стійкості трикотажу до дії різних механічних впливів. Параметри розроблених зразків трикотажу представлені у табл.1.

Таблиця 1

\section{Параметри структури трикотажних полотен}

\begin{tabular}{|c|c|c|c|c|c|}
\hline $\begin{array}{c}\text { Номер } \\
\text { зразка }\end{array}$ & $\begin{array}{c}\text { Довжина } \\
\text { нитки } \\
\text { в петлі, мм }\end{array}$ & $\begin{array}{c}\text { Кількість петельних } \\
\text { стовпчиків у 100 мм } \\
\text { трикотажу Nс }\end{array}$ & $\begin{array}{c}\text { Кількість петельних } \\
\text { рядів у 100 мм } \\
\text { трикотажу Np }\end{array}$ & $\begin{array}{c}\text { Товщина } \\
\text { трикотажу } \\
\text { М, mm }\end{array}$ & $\begin{array}{c}\text { Поверхнева } \\
\text { густина тs, } \\
\text { г/м }\end{array}$ \\
\hline 1 & 7,8 & 46 & 72 & 1,41 & 343 \\
\hline 2 & 8,3 & 44 & 68 & 1,31 & 337 \\
\hline 3 & 8,8 & 42 & 64 & 1,22 & 323 \\
\hline 4 & 8,6 & 64 & 70 & 1,80 & 715 \\
\hline 5 & 9,1 & 60 & 64 & 1,65 & 569 \\
\hline 6 & 9,6 & 50 & 60 & 1,50 & 433 \\
\hline
\end{tabular}

3 метою оцінки рівня захисту розроблених зразків трикотажу досліджені його механічні властивості: стійкість матеріалу до роздирання і проколу. Дослідження з визначення величини опору проколу розроблених зразків трикотажу проведені на розривній машині Kao Tieh KT-7010AZ (рис.2) 3 використанням спеціального пристрою для закріплення проби відповідно до національного стандарту, гармонізованого з європейськими [10]. У ході експерименту встановлено стійкість трикотажу до проколу в залежності від довжини нитки в петлі. Результати представлені у таблиці 2.

Таблиця 2

Результати досліджень на прокол

\begin{tabular}{|c|c|c|c|c|c|c|}
\hline \multirow[t]{3}{*}{ Показники } & \multicolumn{6}{|c|}{ Номер зразка } \\
\hline & \multicolumn{3}{|c|}{ переплетення гладь } & \multicolumn{3}{|c|}{ футероване переплетення } \\
\hline & 1 & 2 & 3 & 4 & 5 & 6 \\
\hline $\begin{array}{l}\text { довжина нитки в } \\
\text { петлі, мм }\end{array}$ & 7,8 & 8,3 & 8,8 & 8,6 & 9,1 & 9,6 \\
\hline площа петлі, мм² & 3,02 & 3,34 & 3,72 & 3,70 & 4,23 & 4,8 \\
\hline опір проколу, Н & 534,07 & 474,15 & 400,5 & 369,51 & 319,01 & 278,12 \\
\hline $\begin{array}{l}\text { величина } \\
\text { деформації, мм }\end{array}$ & 9 & 5 & 4 & 2 & 3 & 4 \\
\hline
\end{tabular}

На підставі даних таблиці 1 побудовані відповідні графіки залежності (рис.3). На величину опору проколу впливає наявність в структурі еластомерної нитки. Введення в структуру трикотажу еластомерної нитки у вигляді футерних накидів з рапортом прокладання 1+3 призводить до зниження опору трикотажу проколу. Зі збільшенням довжини нитки в петлі зразків трикотажу переплетення гладь у діапазоні 7,8ч8,8мм на 12,8\% опір проколу знижується на 25\%. Збільшення довжини нитки в петлі 
зразків трикотажу футерованого переплетення, що містить в структурі еластомерну нитку, в діапазоні 8,6ч9,6мм на 11,6\% призводить до зниження опору проколу на 24,7\%. Таким чином, збільшення довжини нитки в петлі на 1 мм призводить до зниження опору проколу до $25 \%$.

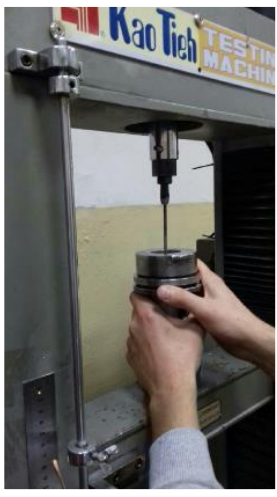

Pис. 2.

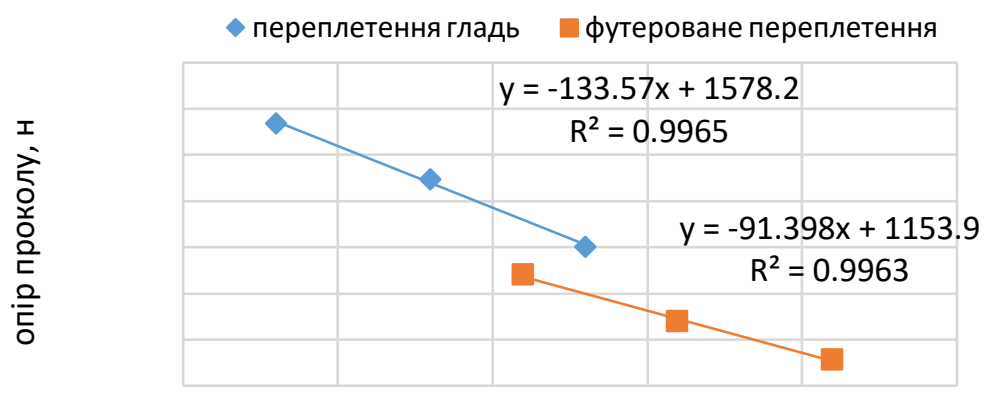

довжина нитки в петлі, мм

Рис.3. Графіки залежності опору проколу від довжини нитки у петлі

У ході досліджень стійкості трикотажу до проколу вивчено характер проколу, а саме деформацію зразка та характер руйнування структури під дією перфоруючого зусилля (таблиці 1 і 2).

Таблиця 3

Деформація зразків під дією зусилля проколу

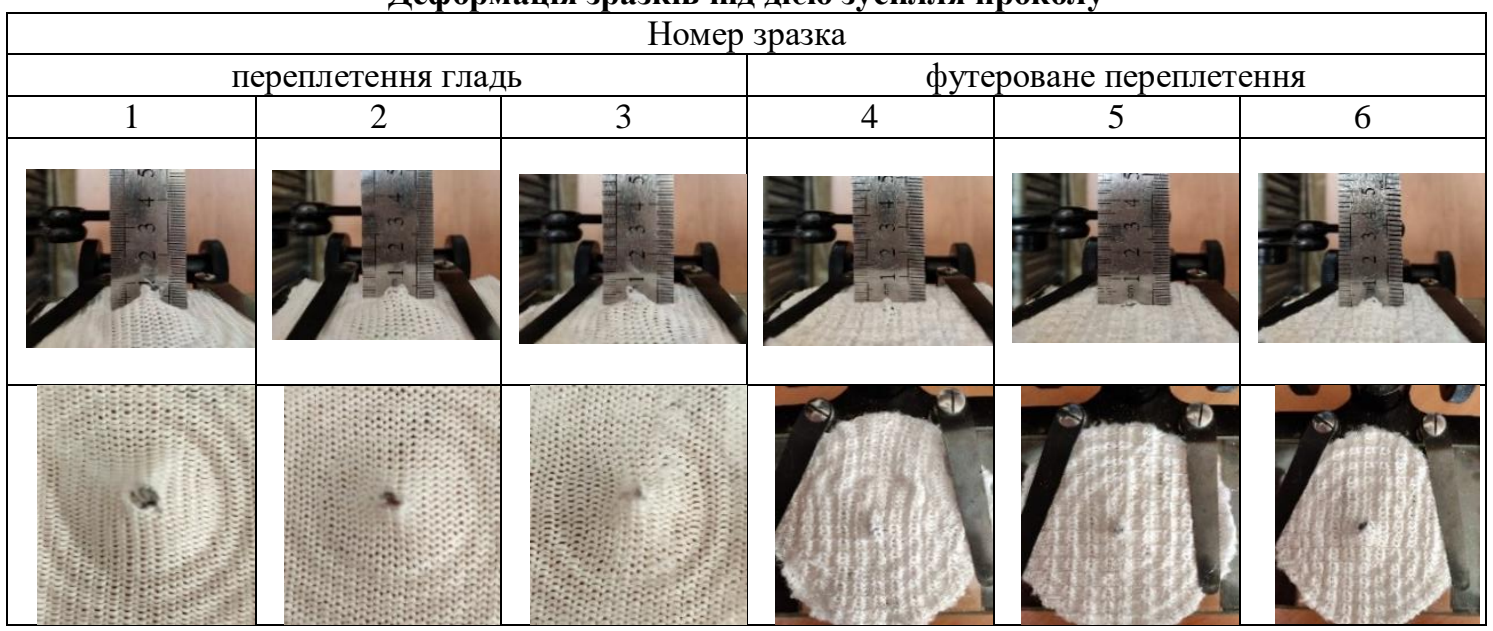

Аналіз зразків дозволяє зробити висновки про вплив щільності в'язання на механізм деформації і характер проколу структури трикотажу. У зразках переплетення гладь зі збільшенням довжини нитки в петлі відповідно збільшується площа петлі. При цьому опиратися проколу під впливом штифта (голки) 3 опорною поверхнею ш1мм буде менша кількість відрізків нитки, зігнутих у петлі. Чим більше щільність трикотажу, тим більша кількість відрізків нитки пручається проколу і тим більша величина деформації структури під впливом штифта. Після досягнення максимальної деформації в структурі трикотажу під впливом штифта нитки, які безпосередньо контактують 3 ним, досягають максимально напруженого стану і починають працювати на розрив. Зі збільшенням довжини нитки в петлі збільшується площа наскрізної пори в області остова петлі, і зі штифтом контактує менша кількість ниток, які чинять опір проколу і призводять до деформації структури трикотажу. У разі подальшого збільшення довжини нитки в петлі штифт контактує з одним відрізком нитки, витягаючи його зі структури, або ж безперешкодно проникає в пори, утворені в структурі кулірного трикотажу в області остовів петель. Таким чином, чим більша щільність трикотажу, тим більша величина наскрізного отвору внаслідок їх руйнування під впливом штифта.

У дослідних зразках, вироблених футерованим переплетенням, що містять в структурі еластомерну нитку, характер деформації зразків під впливом зусилля проколу інший. Еластомерна нитка перешкоджає деформації структури трикотажу під впливом зусилля проколу. Чим більше значення довжини нитки в петлі, тим більша величина деформації структури трикотажу внаслідок того, що деформація розтягування структури трикотажу переважає над пружними властивостями еластомерної нитки, розташованої в структурі трикотажу в поперечному напрямку. Наявність в структурі еластомерної нитки сприяє зменшенню деформації і величини наскрізного отвору, утвореного внаслідок руйнування нитки під впливом зусилля проколу, що слід враховувати при проєктуванні виробу певної асортиментної групи. 
Дослідження стійкості трикотажу до роздираючого зусилля проведено у відповідності до ДСТУ EN 388:2005 на розривній машині Као Tieh моделі KT-7010AZ [2]. У результаті проведених досліджень встановлено рівень роздираючого зусилля дослідних зразків (табл.3). Процес роздирання здійснювався як уздовж лінії петельного стовпчика, так і вздовж лінії петельного ряду. Встановлено, що роздираюче зусилля усіх зразків не залежно від щільності в'язання та напрямку роздирання коливається у діапазоні 217 ч227H в межах похибки вимірювань $5 \%$, що відповідає четвертому найвищому рівню захисту за ДСТУ ЕN 388:2005.

Слід звернути увагу на характер деформації зразків під впливом роздираючого зусилля. При прикладанні роздираючого зусилля вздовж лінії петельного стовпчика на початковому етапі відбувається розпуск петель у точці максимального напруження. У результаті розпуску формуються прямолінійні відрізки з ниток кількох петельних рядів, які у подальшому чинять опір розриву. При цьому ділянки проби (ніжки), заправлені у верхній і нижній затискачі, скручуються вздовж лінії петельного ряду на виворітну сторону трикотажу і формують «шнурок» (джгут). Розрив петельної структури трикотажу відбувається в області «ніжки» проби.

При прикладанні роздираючого зусилля вздовж лінії петельного ряду на початковому етапі відбувається скручування уздовж лінії петельного стовпчика у точці максимального напруження. При цьому на ділянках проби (ніжки), заправлених у верхній та нижній затискачі, відбувається розпуск петель в петельних рядах, Сформовані прямолінійні відрізки нитки в подальшому чинять опір розриву. Ці ділянки скручуються вздовж лінії петельного стовпчика на лицьову сторону трикотажу і формують «шнурок» (джгут). Максимальна напруга і розрив структури відбувається в області «ніжок» проби. Розриву перешкоджають прямолінійні відрізки ниток, сформовані у результаті розпуску петель.

Таблиця 3

Зразки трикотажу після їх дослідження на стійкість до прикладеного роздираючого зусилля

\begin{tabular}{|c|c|c|c|}
\hline Роздирання вздовж лінії петельного стовпчика & \multicolumn{2}{|c|}{ Роздирання вздовж лінії петельного ряду } \\
\hline переплетення гладь & $\begin{array}{c}\text { футероване } \\
\text { переплетення }\end{array}$ & $\begin{array}{c}\text { переплетення гладь } \\
\text { переповетененя }\end{array}$ \\
\hline & &
\end{tabular}

На відміну від зразків переплетення гладь в зразках, вироблених футерованим переплетенням, розпуску петель під впливом роздираючого зусилля, прикладеного як уздовж петельного стовпчика, так i вздовж петельного ряду, перешкоджає наявність у петельних рядах еластомерної нитки у якості футерної, що дозволяє уникнути розпуску петель та забезпечити цілісність структури текстильного матеріалу.

\section{Висновки}

У результаті реалізованих експериментальних досліджень виявлено вплив зміни довжини нитки в петлі та введення у структуру переплетення грунту еластомерної нитки у вигляді футерних накидів та протяжок на опір проколу. Збільшення довжини нитки в петлі на 1 мм призводить до зниження опору проколу близько $25 \%$.

На механізм деформації і характер проколу структури трикотажу впливає щільність в'язання трикотажу. Збільшення довжини нитки в петлі призводить до зростання наскрізної пористості та, як наслідок, під впливом штифта (голки) з опорною поверхнею ш1мм проколу опирається менша кількість відрізків нитки, зігнутих у петлі. Чим більше щільність трикотажу, тим більша кількість відрізків нитки пручається проколу і тим більші величина деформації структури під впливом штифта та величина наскрізного отвору внаслідок іх руйнування. Після досягнення максимальної деформації в структурі трикотажу під впливом штифта нитки, які безпосередньо контактують з голкою, досягають максимально напруженого стану і починають працювати на розрив.

Незалежно від щільності в'язання та напрямку дії величина роздираючого зусилля коливається у діапазоні 217 ч227Н в межах похибки вимірювань $5 \%$. При цьому розрив петельної структури трикотажу внаслідок прикладеного роздираючого зусилля відбувається в області «ніжки» проби. 
Подяка. Робота виконувалась у рамках спільного українсько-литовського науково-дослідного проєкту «Трикотажні матеріали для засобів індивідуального захисту від механічних пошкоджень та дії полум'я (акронім - PERPROKNIT)» за підтримки Міністерства освіти і науки України.

\section{Список використаної літератури}

1. ГОСТ 12.4.103-83. Система стандартов безопасности труда (ССБТ). Одежда специальная защитная, средства индивидуальной защиты ног и рук. Классификация. Межгосударственный стандарт. - Москва: Издательство стандартов, 2003. - 9 с.

2. ДСТУ EN 388:2005. Рукавички для захисту від механічних ушкоджень. Загальні технічні вимоги та методи випробування. - Київ: Держспоживстандарт України, 2008. - 16 с.

3. ДСТУ EN 420-2001. Загальні вимоги до рукавиць. - Київ: Державний комітет України 3 питань технічного регулювання та споживчої політики, 2003. - 18 с.

4. Кизимчук О. П. Аналіз асортименту захисних текстильних матеріалів / О. П. Кизимчук, Л. М. Мельник, І. В. Срмоленко // Вісник Київського національного університету технологій та дизайну. Технічні науки. - 2016. - № 6 (104). - С. 115-125.

5. BS EN 388:2016. Protective gloves against mechanical risks, published by BSI Standards Limited 2016, The British Standarts Institution. European standard, 2016. -7 p.

6. Боброва С. Ю. Розробка трикотажу для захисту рук від механічних ушкоджень / С. Ю. Боброва // Вісник Хмельницького національного університету. Серія: Технічні науки. - 2018. - № 5 (265). - C. 242-246.

7. Боброва С. Ю. Деформаційні властивості трикотажу для захисту рук від механічних ушкоджень / С. Ю. Боброва, Д. О. Шипко, Л. С. Галавська // Вісник Хмельницького національного університету. Серія: Технічні науки. - 2019. - № 1 (269). - С. 96-99.

8. Mikucioniene D. Ultra-strong knits for personal protective equipment / D. Mikucioniene, L. Halavska, S. Bobrova, T. Ielina, and R. Milasius // Appl. Sci. - 2020. Vol.10(18), 6197; https://doi.org/10.3390/app10186197

9. Офіційний сайт компанії «BeijingTongyizhong». [Електронний ресурс]. Режим доступу: http://www.bjtyz.com/en/index.php?optionid=681\&auto_id=5.

10. ДСТУ EN 863-2001 (EN 863:1995, IDT). Одяг захисний механічні властивості. Метод визначання опору проколюванню. - Київ: УкрНДІТП, 2002. - 8 с.

\section{References}

1. GOST 12.4.103-83. Sistema standartov bezopasnosti truda (SSBT). Odezhda spetsial'naya zashchitnaya, sredstva individual'noy zashchity nog i ruk. Klassifikatsiya [Interstate Standart 12.4.103-83. Occupational safety standarts system. Special protective clothes, personal means of hands and legs protection. Classification]. Moscow, Izdatelstvo standartov, 2003. 9 p.

2. DSTU EN 388:2005. Rukavychky dlia zakhystu vid mekhanichnykh ushkodzhen. Zahalni tekhnichni vymohy ta metody vyprobuvannia [State Standart EN 388:2005. Gloves for protection against mechanical hazards. General technical requirements and methods of testing]. Kyiv, 2008. 16 p.

3. DSTU EN 420-2001. Zahalni vymohy do rukavyts [State Standart EN 420-2001. General requirements for gloves]. Kyiv, 2003. 18 p.

4. Kyzymchuk O.P., Mel'nyk L.M., Yermolenko I.V. Analiz asortymentu zakhysnykh tekstyl'nykh materialiv. Visnyk Kyivs'koho natsional'noho universytetu tekhnolohij ta dyzajnu. Tekhnichni nauky. Kyiv. 2016. Volume 6 (104). pp. 115-125.

5. BS EN 388:2016. Protective gloves against mechanical risks, published by BSI Standards Limited 2016, The British Standarts Institution. European standard, 2016. 7 p.

6. Bobrova S.Yu. Rozrobka trykotazhu dlia zakhystu ruk vid mekhanichnykh nebezpek. Khmelnytskyi. Visnyk Khmelnytskoho natsionalnoho universytetu. Technical sciences. Khmelnytskyi. 2018. Volume 265.Issue 5. pp. 242-246.

7. Bobrova S.Yu, Shypko D.O., Halavska L.Ye. Deformatsiini vlastyvosti trykotazhu dlia zakhystu ruk vid mekhanichnykh ushkodzhen Visnyk Khmelnytskoho natsionalnoho universytetu. Technical sciences. Khmelnytskyi. 2019. Volume 269. Issue 1. pp. 96-99.

8. Mikucioniene D. Halavska L., Bobrova S., Ielina T., and Milasius R. Ultra-strong knits for personal protective equipment, Appl. Sci., 2020, Vol.10(18), 6197. https://doi.org/10.3390/app10186197

9. Official website of the company Beijing Tongyizhong. Available at http://www.bjtyz.com/en/index. php?optionid=681\&auto_id=16.

10. DSTU EN 863-2001 (EN 863:1995, IDT). Odiah zakhysnyi mekhanichni vlastyvosti. Metod vyznachannia oporu prokoliuvanniu [State Standart DSTU EN 863-2001 (EN 863:1995, IDT). Protective clothing mechanical properties. Test method: puncture resistance]. Kyiv, 2002. -8 p. 